University of Nebraska - Lincoln

DigitalCommons@University of Nebraska - Lincoln

\title{
In Vivo Study on Combined Toxicity of Metarhizium anisopliae (Deuteromycotina: Hyphomycetes) Strain ESC-1 with Sublethal Doses of Chlorpyrifos, Propetamphos, and Cyfluthrin Against German Cockroach (Dictyoptera: Blattellidae)
}

Pari Pachamuthu

University of Nebraska-Lincoln

Shripat T. Kamble

Universitiy of Nebraska--Lincoln, skamble1@unl.edu

Follow this and additional works at: https://digitalcommons.unl.edu/entomologyfacpub

Part of the Entomology Commons

Pachamuthu, Pari and Kamble, Shripat T., "In Vivo Study on Combined Toxicity of Metarhizium anisopliae (Deuteromycotina: Hyphomycetes) Strain ESC-1 with Sublethal Doses of Chlorpyrifos, Propetamphos, and Cyfluthrin Against German Cockroach (Dictyoptera: Blattellidae)" (2000). Faculty Publications:

Department of Entomology. 312.

https://digitalcommons.unl.edu/entomologyfacpub/312

This Article is brought to you for free and open access by the Entomology, Department of at DigitalCommons@University of Nebraska - Lincoln. It has been accepted for inclusion in Faculty Publications: Department of Entomology by an authorized administrator of DigitalCommons@University of Nebraska - Lincoln. 


\title{
In Vivo Study on Combined Toxicity of Metarhizium anisopliae (Deuteromycotina: Hyphomycetes) Strain ESC-1 with Sublethal Doses of Chlorpyrifos, Propetamphos, and Cyfluthrin Against German Cockroach (Dictyoptera: Blattellidae)
}

\author{
PARI PACHAMUTHU AND SHRIPAT T. KAMBLE ${ }^{1}$
}

Department of Entomology, University of Nebraska, NE 68583-0816

\begin{abstract}
J. Econ. Entomol. 93(1): 60-70 (2000)
ABSTRACT The effect of Metarhizium anisopliae (Metschnikoff) Sorokin strain ESC-1 alone and in combination with sublethal doses of commercial formulations of chlorpyrifos, propetamphos and cyfluthrin on mortality of CSMA strain of German cockroach, Blattella germanica (L.), was determined by conducting in vivo studies that included 3 bioassays. Spores of $M$. anisopliae cultured on SDAY media had germination of $>90 \%$. Based on bioassay 1 , doses ranging from 0.5 to $300 \mathrm{ppm}$ of chlorpyrifos and propetamphos, and 0.05 to $40 \mathrm{ppm}$ of cyfluthrin were selected for bioassays 2 and 3. Cockroach mortality ranged from 5 to $20 \%$ for insecticides alone and 48 to $70 \%$ for insecticides + M. anisopliae in bioassay 2 . In bioassay 3, mortality ranged from 15 to $60 \%$ for insecticides and 57.5 to $92.5 \%$ for insecticides + M. anisopliae. Percentage of cockroach mortality resulting from insecticide + M. anisopliae combinations was significantly higher than insecticide alone. Mortality was also significantly higher in certain insecticide + M. anisopliae combinations than M. anisopliae alone. There was no significant interaction between $M$. anisopliae and insecticides with their concentrations in bioassay 2 , indicating an additive effect. But in bioassay 3, a significant interaction was observed when M. anisopliae was combined with multiple insecticide concentrations. The interaction indicated an additive effect for chlorpyrifos and cyfluthrin, and a synergistic effect for propetamphos. There were significant differences in $\mathrm{LT}_{50}$ among various treatment combinations. M. anisopliae alone or insecticide $+M$. anisopliae combinations did not affect body weight in treated German cockroaches.
\end{abstract}

KEY WORDS Metarhizium anisopliae, Blattella germanica, insecticides, combined toxicity, interaction

The German COCKROACH, Blattella germanica (L.), is a major cosmopolitan indoor pest, mainly in dwellings, childcare centers, schools, healthcare facilities, commercial laundromats, breweries, grocery stores, food processing plants, and restaurants. German cockroaches are primarily controlled through the use of insecticides. The most frequently used insecticides against German cockroach are chlorpyrifos, propetamphos, diazinon (organophosphates), propoxur, bendiocarb (carbamates), cypermethrin, cyfluthrin, deltamethrin, fenvalerate, lambda-cyhalothrin, and tralomethrin (pyrethroids) (Benson and Zungoli 1997). Despite many benefits from insecticides, factors such as insecticide resistance to organophosphate, carbamate, and pyrethroid compounds (Cochran 1989, Scott et al. 1990, Rust and Reierson 1991, Zhai and Robinson 1992, Hemingway et al. 1993, Rust et al. 1993), environmental concerns, and increased developmental costs of new insecticides have intensified the search for safer compounds (Lacey and Undeen 1986, Charnley 1989, Benson and Zungoli 1997) with novel modes of action and environmentally safe bio-

\footnotetext{
${ }^{1}$ To whom reprint requests should be addressed.
}

logical products. Recently, the entomopathogenic fungi have received some attention for their use in urban pest management programs.

Approximately 750 species of entomopathogenic fungi are found in many habitats such as soil (McCoy 1990, Quintela and McCoy 1997), plants, and aquatic ecosystems (McCoy 1990). The entomopathogenic fungus Metarhizium anisopliae (Metschnikoff) Sorokin has been isolated from 200 insects species including the orders Lepidoptera, Coleoptera, Orthoptera, and Hemiptera (Charnley 1989, Zimmermann 1993). There are few reports on the use of this fungus for urban pest management (Gunner et al. 1991; Kelley-Tunis et al. 1995; Kaakeh et al. 1996, 1997; Pachamuthu et al. 1999). According to Gunner et al. (1991), M. anisopliae strain PA-2 required $\approx 6$ wk to produce $90 \%$ mortality in German cockroaches, whereas Kaakeh et al. (1996) reported 26-30 d to achieve $90 \%$ or higher mortality with M. anisopliae strain ESC-1 in controlling German cockroaches by contact method. M. anisopliae was manufactured commercially as Bio-Path by Ecoscience for German cockroach control. The major limitations in the use of $M$. anisopliae were an extended time to cause sufficient 
insect mortality (McCoy 1990), and its inconsistent performance under field conditions (Quintela and McCoy 1998). Design and shelf life of the Bio-path chambers and high humidity requirement also limited the success of Bio-Path (Gunner et al. 1991, Kaakeh et al. 1996). One of the options for improving the efficacy of the entomopathogenic fungi is to incorporate the fungal pathogens with sublethal doses of insecticides (Anderson and Roberts 1983, Salama et al. 1984, Charnley 1989, Sanyang and Van Emden 1996, Hiromori and Nishigaki 1998). Data from in vivo compatibility studies have indicated that M. anisopliae and insecticides are compatible, and their combination can have a synergistic, antagonistic (Salama et al. 1984; Kaakeh et al. 1997; Quintela and McCoy 1997, 1998) or additive effect (Salama et al. 1984, Anderson et al. 1989).

McCoy (1990) stated that physiological starvation or nutritional deficiency in the M. anisopliae infected host is one of the mode of action caused by this fungus. Hajek (1989), Moore et al. (1992), and Sanyang and Van Emden (1996) clearly demonstrated that there was a significant reduction in the food consumption by entomopathogenic fungi-infected insects. Thus, in addition to its effect on mortality, M. anisopliae can also reduce food consumption in infected insects. The potential impact in the use of M. anisopliae and insecticides combination has been evaluated only once in a German cockroach control program (Kaakeh et al. 1997). Compatibility between M. anisopliae and insecticides can lead to a reduced use of insecticides (Richter and Fuxa 1984, Quintela and McCoy 1997) for cockroach control thereby reducing human exposure (Sanyang and Van Emden 1996) in the urban structures.

The research objectives were to enhance the lethal effect of M. anisopliae strain ESC-1 by using it in combination with sublethal doses of chlorpyrifos, propetamphos, and cyfluthrin against the German cockroaches; to ascertain the $\mathrm{LT}_{50}$; to determine if interactions (synergistic, additive, and antagonist) occur between M. anisopliae and insecticides; and to measure the effect on weight gain in German cockroaches during the infection process.

\section{Materials and Methods}

Insects. We used the Chemical Specialities and Manufacture Association (CSMA) strain, an insecticide susceptible strain of German cockroach, as the target insect. German cockroaches were reared on Purina dog chow (Ralston Purina, St. Louis, MO) and water, and confined in Plexiglas containers (59 by 24 by $24 \mathrm{~cm}$ ). The cockroaches were maintained at $27 \pm$ $2^{\circ} \mathrm{C}, 60 \pm 10 \% \mathrm{RH}$, and a photoperiod of $12: 12$ (L:D) h.

Insecticides. The insecticides used were chlorpyrifos (Dursban Pro, 23.5\% [AI], Dow Agroscience, Indianapolis, IN), propetamphos (Safrotin, $18.9 \%$ [AI], Novartis, Dallas, TX), and cyfluthrin (Tempo, 24.3\% [AI], Bayer, Kansas City, MO). In our study, the commercial formulation of all 3 insecticides used was emulsified concentrate (EC). The doses used were below the maximum label rates $(5,000 \mathrm{ppm}$ [milligrams per liter] for chlorpyrifos and propetamphos, and $500 \mathrm{ppm}$ [milligrams per liter] for cyfluthrin). Because the commercial formulation was used, the sublethal doses (starting at $1 / 10$ of the label rate) were selected from the field-recommended doses and insecticides were suspended in water as recommended by the manufactures (Tedders 1981, Samuels et al. 1989, Li and Holdom 1994). This experimental protocol of mixing commercial formulation with water or surfactant plus water was also used by other researchers (Anderson and Roberts 1983, Salama et al. 1984, Anderson et al. 1989, Quintela and McCoy 1997). In contrast, if technical grade material had been used then it would have been essential to produce the probit line with $95 \%$ CL and the sublethal doses could have been selected from the probit analysis for subsequent bioassays.

Production and Harvest of Conidia. SDAY media for conidial production of M. anisopliae was prepared as described by Moorhouse et al. (1992) and Pachamuthu et al. (1999). Ten microliters of the spore suspension in $0.05 \%$ Triton $\mathrm{X}-100$ was placed in the center of each petri dish containing the media and dishes were sealed with parafilm. Spores cultures in sealed petri dishes were incubated at constant temperature $\left(27 \pm 2^{\circ} \mathrm{C}\right)$ in dark for $14-21 \mathrm{~d}$. Conidia were then harvested by submerging the colonies in distilled water containing $0.05 \%$ Triton $\mathrm{X}-100$. Colonies were scraped with sterile spatula, filtered through 8-layered cheese cloth (style 280, Chicopee Mills, New York, $\mathrm{NY})$, centrifuged $\left(3,500 \times \mathrm{g}, 15 \mathrm{~min}, 4^{\circ} \mathrm{C}\right)$ and resuspended in $0.05 \%$ Triton $\mathrm{X}-100$. The spore concentration was determined using Neubauer hemocytometer. Spore concentration was determined by using the formula: [total number of spores from both sides divided by $\left.2 \times\left(0.1 \mathrm{~mm}^{3}\right)\right] \times\left[1 \times 10^{3} \mathrm{~mm}^{3}\right.$ per milliliter], where $0.1 \mathrm{~mm}^{3}$ is the height and $1 \times 10^{3} \mathrm{~mm}^{3}$ is the total area of hemocytometer.

Determining the Percentage of Germination. The percentage of spore germination used in the topical bioassay was determined by placing $\approx 5 \mu \mathrm{l}$ of the spore solution in the center of each petri dish and spreading with a sterile glass rod. Petri dishes containing conidial cultures were sealed with parafilm and incubated at $27 \pm 2^{\circ} \mathrm{C}$ for $12 \mathrm{~h}$ and then observed for germ tube development.

Bioassay 1 for Establishing Initial Insecticide Doses Yielding Minimum Cockroach Mortality. The insecticide concentrations (water diluted) used in bioassay 1 were $0.5,5,50,100,200,300,400$, and $500 \mathrm{ppm}$ ( $\mathrm{mg} /$ liter) for chlorpyrifos and propetamphos and $0.05,0.5,5,10,20,30,40$, and $50 \mathrm{ppm}(\mathrm{mg} /$ liter $)$ for cyfluthrin. Topical assays were conducted by applying $1 \mu \mathrm{l}$ of insecticide solution to the 1 st ventral abdominal segment; each treatment was replicated 3 times with 10 cockroaches per treatment. Cockroaches in the control group were treated with distilled water. Treated cockroaches from each treatment were placed in individual Plexiglas containers ( 15 by $6 \mathrm{~cm}$ ) and maintained in the growth chambers at $27 \pm 2^{\circ} \mathrm{C}$, 
$\approx 85 \% \mathrm{RH}$, and a photoperiod of 6:18 (L:D) h. Mortality was recorded $48 \mathrm{~h}$ after treatment.

Bioassay 2 for Determining the Baseline Combined Effect of M. anisopliae with Selected Sublethal Doses of Insecticides. Topical assays were conducted by initially applying $1 \mu \mathrm{l}$ of $M$. anisopliae spore solution in $0.05 \%$ Triton X-100; $24 \mathrm{~h}$ later, $1 \mu \mathrm{l}$ of different concentrations of insecticides solution mixed with distilled water were applied on the 1st ventral abdominal segment using the Hamilton microliter syringe (Hamilton, Reno, NV). The concentration used for M. anisopliae treatment was $4.18 \times 10^{8}$ spores per milliliter, and we used the previously calculated $\mathrm{LD}_{50}$ (Pachamuthu et al. 1999). The treatments used were distilled water + Triton X-100 (0 ppm), M. anisopliae $+0 \mathrm{ppm}$, chlorpyrifos $0.5,5,50 \mathrm{ppm}$, chlorpyrifos $0.5 \mathrm{ppm}+M$. anisopliae, chlorpyrifos $5 \mathrm{ppm}+M$. anisopliae, and chlorpyrifos $50 \mathrm{ppm}+$ M. anisopliae; propetamphos $0.5,5,50 \mathrm{ppm}$, propetamphos $0.5 \mathrm{ppm}+$ M. anisopliae, propetamphos $5 \mathrm{ppm}+$ M. anisopliae, and propetamphos $50 \mathrm{ppm}+$ M. anisopliae; cyfluthrin $0.05,0.5$, and $5 \mathrm{ppm}$, cyfluthrin, $0.05 \mathrm{ppm}+$ M. anisopliae, cyfluthrin $0.5 \mathrm{ppm}+M$. anisopliae, and cyfluthrin $5 \mathrm{ppm}+M$. anisopliae. Ten adult males were used per treatment and each treatment was replicated 4 times. The treated cockroaches from each treatment were placed in individual Plexiglas containers ( 15 by $6 \mathrm{~cm}$ ) and maintained in the growth chambers at $27 \pm 2^{\circ} \mathrm{C} \approx 85 \% \mathrm{RH}$, and a photoperiod of 6:18 (L:D) h. Food and water were placed inside the containers and they were changed once every $2 \mathrm{~d}$. Mortality was observed daily for $21 \mathrm{~d}$ and the dead cockroaches were removed to prevent contamination.

Bioassay 3 for Enhancing the Combined Effect of $M$. anisopliae with Higher Sublethal Doses of Insecticides. Four concentrations of chlorpyrifos, propetamphos, and cyfluthrin were used in bioassay 3 . The treatments used were chlorpyrifos $0,100,200$, and 300 ppm, chlorpyrifos $0 \mathrm{ppm}+$ M. anisopliae, chlorpyrifos $100 \mathrm{ppm}+$ M. anisopliae, chlorpyrifos $200 \mathrm{ppm}+M$. anisopliae, chlorpyrifos $300 \mathrm{ppm}+$ M. anisopliae; propetamphos $0,100,200$, and $300 \mathrm{ppm}$, propetamphos 0 $\mathrm{ppm}+$ M. anisopliae, propetamphos $100 \mathrm{ppm}+M$. anisopliae, propetamphos $200 \mathrm{ppm}+$ M. anisopliae, propetamphos $300 \mathrm{ppm}+$ M. anisopliae; cyfluthrin 0 , 20,30 , and $40 \mathrm{ppm}$, cyfluthrin $0 \mathrm{ppm}+\mathrm{M}$. anisopliae, cyfluthrin $20 \mathrm{ppm}+$ M. anisopliae, cyfluthrin $30 \mathrm{ppm}+$ M. anisopliae, and cyfluthrin $40 \mathrm{ppm}+M$. anisopliae. The concentration of M. anisopliae, number of insects, replication, as well as the topical application and experimental protocol used in bioassay 3 were the same as bioassay 2 .

However, mortality was observed daily for all treatments and the dead cockroaches were removed. Data were collected for $60 \mathrm{~d}$ and the lethal time was estimated by probit analysis (LeOra Software 1991). Conventionally, probit analysis has been used for estimating the lethal time where doses are substituted by time (Cochran 1987, 1989; Kaakeh et al. 1997; Quintela and McCoy 1997). The regression lines are then determined by using the cumulative mortality versus $\log _{10}$ of time (days) and treatments are considered to be significantly different if there was no overlap of their 95\% CL (Cochran 1987, 1989; Robertson and Preisler 1992; Kaakeh et al. 1996, 1997).

Effect on Cockroach Body Weight from M. anisopliae Alone and Insecticide Plus M. anisopliae During the Infection Process. The cockroaches that were used in bioassay 3 were also used for monitoring the effect of treatment combination on body weight. The treated cockroaches from each treatment were placed in individual Plexiglas containers ( 15 by $6 \mathrm{~cm}$ ) and maintained in the growth chambers at $27 \pm 2^{\circ} \mathrm{C}, \approx 85 \% \mathrm{RH}$, and a photoperiod of 6:18 (L:D) h. Ten cockroaches were used per treatment and each treatment was replicated 4 times. Food and water were placed inside the containers and they were changed once in $2 \mathrm{~d}$. Body weight was measured at a 2-d interval for $20 \mathrm{~d}$ (11 observations) and the dead cockroaches were removed to prevent contamination. The body weight was then converted into percentage to determine the change during the infection process, using the following formula: body weight on the observation day divided by body weight on the treatment day and multiplied by 100 .

Experimental Design and Statistical Analysis. The treatment design for the bioassays 2 and 3 , was a $3 \times$ $2 \times 4$ factorial arrangement, with 3 insecticide (chlorpyrifos, propetamphos, and cyfluthrin), 2 spore concentrations (with spore and without spores), and 4 concentrations of each insecticide (Sanyang and Van Emden 1996; Quintela and McCoy 1997, 1998). In bioassay 2 , the concentrations used were $0,0.5,5$, and $50 \mathrm{ppm}$ for chlorpyrifos and propetamphos, and 0, 0.05, 0.5 , and $5 \mathrm{ppm}$ for cyfluthrin. In bioassay 3 , the concentrations used were $0,100,200$, and $300 \mathrm{ppm}$ for chlorpyrifos and propetamphos, and 0, 20, 30, and 40 ppm for cyfluthrin. Thus, there were 4 concentrations for each insecticide (chlorpyrifos, propetamphos, and cyfluthrin) in both bioassay 2 and 3. The experimental design was a randomized complete block design. Analysis of variance (ANOVA) was performed using PROC MIXED. Slopes were also compared using the regression analysis (SAS Institute 1996). Significant differences in the treatment combinations by factorial analysis will indicate that there is interaction between $M$. anisopliae plus insecticide combination and the effect observed might be synergistic or antagonistic. In contrast if there is no significant difference in $M$. anisopliae plus insecticide combination it will imply that the effects are additive (Quintela and McCoy 1997, 1998). Body weight data were also analyzed using the procedure described above with one modification, which included the data being treated as repeated measures because observations were taken from the same experimental units over a period. Additional chi-square tests were performed to validate the type of interaction (additive, synergistic or antagonistic). The chi-square statistic was used for comparing the expected and observed mortality by various treatment combinations. The expected values were calculated using the formula: $O_{i}+O_{m}\left(1-O_{i}\right)$, where $O_{i}$ was the proportional mortality caused by insecticides and $O_{m}$ was the proportional mortality caused by 
Table 1. Toxicity of serial insecticide doses yielding minimum mortality in German cockroaches after $48 \mathrm{~h}$ study in bioassay 1

\begin{tabular}{lcc}
\hline \hline \multicolumn{1}{c}{ Treatment (ppm) ${ }^{a}$} & $n$ & $\begin{array}{c}\% \text { mortality } \\
\pm \text { SEM }\end{array}$ \\
\hline $\begin{array}{l}\text { Chlorpyrifos }(0.5),(5), \text { and } \\
\quad 50)\end{array}$ & 30,30 and 30 & 0,0 and 0 \\
Chlorpyrifos (100) & 30 & $6.67 \pm 5.77$ \\
Chlorpyrifos (200) & 30 & $16.67 \pm 11.54$ \\
Chlorpyrifos (300) & 30 & $33.33 \pm 5.77$ \\
Chlorpyrifos (400) & 30 & $56.67 \pm 5.77$ \\
Chlorpyrifos (500) & 30 & $63.33 \pm 11.54$ \\
Propetamphos (0.5), (5), & 30,30, and 30 & 0,0, and 0 \\
$\quad$ and (50) & 30 & 0 \\
Propetamphos (100) & 30 & $6.67 \pm 5.77$ \\
Propetamphos (200) & 30 & $13.33 \pm 15.27$ \\
Propetamphos (300) & 30 & $66.67 \pm 5.77$ \\
Propetamphos (400) & 30 & $93 \pm 12$ \\
Propetamphos (500) & & \\
Cyfluthrin (0.05), (0.5), (5) & $30,30,30$, and 30 & $0,0,0$ and 0 \\
$\quad$ and (10) & & \\
Cyfluthrin (20) & 30 & $6.67 \pm 5.77$ \\
Cyfluthrin (30) & 30 & $13.33 \pm 5.77$ \\
Cyfluthrin (40) & 30 & $23.33 \pm 5.77$ \\
Cyfluthrin (50) & 30 & $50 \pm 10.00$ \\
Water (Control) & 30 & 0 \\
\hline
\end{tabular}

${ }^{a}$ Each treatment was replicated 3 times with 10 male German cockroaches per treatment.

M. anisopliae (Richter and Fuxa 1984, Salama et al. 1984, Morris et al. 1994). The expected value was then converted into percentage mortality. If the calculated chi-square value exceeds the tabular value, then it indicates either synergistic or antagonistic interaction. In contrast, if the tabular value exceeds calculated chi-square value, then it indicates a additive effect.

\section{Results}

Establishing Initial Insecticide Doses Yielding Minimum Cockroach Mortality (Bioassay 1). We observed 0-93\% mortality (Table 1) in the initial experiment $48 \mathrm{~h}$ after treatment. The highest cockroach mortality was observed at 500 ppm of propetamphos, followed by 400-500 ppm of chlorpyrifos, and $50 \mathrm{ppm}$ of cyfluthrin. There was no cockroach mortality in 12 of the 25 treatments. Bioassay 1 was conducted to determine the impact of mortality within the $48 \mathrm{~h}$ after treatment. It was not monitored for $21 \mathrm{~d}$ because the objective of this experiment was to select doses that would allow sufficient time for conidia to form the germ tube and appressoria. High mortality by insecticide during this period affects the effectiveness of fungus because conidia requires a minimum of 12-24 $\mathrm{h}$ for germ tube development and appressoria (Butt et al. 1995, Pachamuthu et al. 1999). Based on initial test results, the concentrations (5-50 ppm for chlorpyrifos and propetamphos, and 0.05-5 ppm for cyfluthrin) yielding zero mortality within $48 \mathrm{~h}$ after treatments were selected for bioassay 2. Although concentration ranging from 100 to $300 \mathrm{ppm}$ of chlorpyrifos and propetamphos and 20-40 ppm of cyfluthrin caused mortality, these doses were used in bioassay 3 to determine if increased insecticide concentration will have any effect on mortality and interaction. Because we ob-
Table 2. Toxicity of chlorpyrifos (ppm) and chlorpyrifos $(\mathrm{ppm})+\mathrm{M}$. anisopliae $\left(4.18 \times 10^{8}\right.$ spores per milliliter $)$ in German cockroaches after 21 d

\begin{tabular}{|c|c|c|c|c|}
\hline Treatment $(\mathrm{ppm})^{a}$ & $n$ & $\begin{array}{l}\% \text { mortality } \\
\pm \text { SEM }\end{array}$ & Effect $^{b}$ & $\chi^{2^{c}}$ \\
\hline \multicolumn{5}{|c|}{ Bioassay 2} \\
\hline $\begin{array}{l}\text { Distilled water }+ \\
\text { Triton X-100 }\end{array}$ & 40 & $7.50 \pm 5.00$ & - & - \\
\hline M. anisopliae & 40 & $50.00 \pm 14.00$ & - & 一 \\
\hline Chlorpyrifos (0.5) & 40 & $10.00 \pm 8.00$ & - & - \\
\hline Chlorpyrifos (5) & 40 & $5.00 \pm 5.00$ & - & - \\
\hline Chlorpyrifos (50) & 40 & $10.00 \pm 8.00$ & - & - \\
\hline $\begin{array}{l}\text { Chlorpyrifos }(0.5)+ \\
\text { M. anisopliae }\end{array}$ & 40 & $48.00 \pm 15.00$ & Additive & 1.02 \\
\hline $\begin{array}{l}\text { Chlorpyrifos }(5)+ \\
\text { M. anisopliae }\end{array}$ & 40 & $50.00 \pm 14.00$ & Additive & 0.12 \\
\hline $\begin{array}{l}\text { Chlorpyrifos }(50)+ \\
\text { M. anisopliae }\end{array}$ & 40 & $60.00 \pm 14.00$ & Additive & 0.45 \\
\hline \multicolumn{5}{|c|}{ Bioassay 3} \\
\hline $\begin{array}{l}\text { Distilled water }+ \\
\text { Triton X-100 }\end{array}$ & 40 & $7.50 \pm 5.00$ & - & - \\
\hline M. anisopliae & 40 & $57.50 \pm 5.00$ & - & 一 \\
\hline Chlorpyrifos (100) & 40 & $20.00 \pm 8.00$ & - & - \\
\hline Chlorpyrifos (200) & 40 & $17.50 \pm 9.00$ & - & - \\
\hline Chlorpyrifos (300) & 40 & $60.00 \pm 8.00$ & - & - \\
\hline $\begin{array}{l}\text { Chlorpyrifos }(100)+ \\
\text { M. anisopliae }\end{array}$ & 40 & $57.05 \pm 5.00$ & Additive & 0.59 \\
\hline $\begin{array}{l}\text { Chlorpyrifos }(200)+ \\
\text { M. anisopliae }\end{array}$ & 40 & $80.00 \pm 14.00$ & Additive & 3.49 \\
\hline $\begin{array}{l}\text { Chlorpyrifos }(300)+ \\
\text { M. anisopliae }\end{array}$ & 40 & $90.00 \pm 8.00$ & Additive & 1.09 \\
\hline
\end{tabular}

Chi-square values calculated using the formula: (observed \% mortality - expected $\%$ mortality $)^{2} /$ expected $\%$ mortality $\left(\chi^{2}=3.84, \mathrm{df}=\right.$ $1, \alpha=0.05$ ).

${ }^{a}$ Each treatment (containing 10 males) was replicated 4 times.

${ }^{b}$ Dashes represent no effect.

${ }^{c}$ Dashes represent no value.

served some mortality at higher doses in bioassay 1 , we applied $M$. anisopliae first followed by insecticide application in bioassay 2 and 3. Based on the research by Butt et al. (1995) and Pachamuthu et al. (1999), 12-24 $\mathrm{h}$ should be sufficient for germ tube development which is the 1st step in the disease initiation by entomopathogenic fungi.

Determining the Baseline Combined Effect of $\boldsymbol{M}$. anisopliae with Selected Sublethal Doses of Insecticides (Bioassay 2). Percentage of germination $\pm \mathrm{SE}$ mean of $M$. anisopliae for the 4 replications used in study were: $91 \pm 2.82,93 \pm 2.75,91 \pm 1.82$, and $91 \pm$ 1.41 , respectively. Mortality was significantly influenced by insecticides $(F=3.97 ; \mathrm{df}=2,69 ; P=0.0234)$, concentration $(F=2.95$; $\mathrm{df}=3,69 ; P=0.0386)$, and $M$. anisopliae $(F=427.83 ; \mathrm{df}=1,69 ; P=0.0001)$. Based on the cumulative mortality (with and without spores) caused by each insecticide, propetamphos (37\%) was more effective than chlorpyrifos $(30 \%)$ and cyfluthrin $(31 \%)$, but there was no difference between chlorpyrifos and cyfluthrin $(t=-0.46$, df $=69, P=$ $0.648)$. In chlorpyrifos $+M$. anisopliae combinations (Table 2), mortality ranged from 48 to $60 \%$ and this mortality was significantly different from chlorpyrifos alone $(P=0.0001)$. In propetamphos $+M$. anisopliae combinations (Table 3 ), the mortality was $65-70 \%$ and it was also significantly greater than propetamphos 
Table 3. Toxicity of propetamphos (ppm) and propetamphos $(\mathrm{ppm})+M$. anisopliae $\left(4.18 \times 10^{8}\right.$ spores per milliliter $)$ in German cockroaches after $21 \mathrm{~d}$

\begin{tabular}{|c|c|c|c|c|}
\hline Treatment $(\mathrm{ppm})^{a}$ & $n$ & $\begin{array}{l}\% \text { mortality } \\
\pm \text { SEM }\end{array}$ & Effect $^{b}$ & $\chi^{2 c}$ \\
\hline \multicolumn{5}{|c|}{ Bioassay 2} \\
\hline $\begin{array}{l}\text { Distilled water }+ \\
\text { Triton X-100 }\end{array}$ & 40 & $7.50 \pm 5.00$ & - & - \\
\hline M. anisopliae & 40 & $50.00 \pm 14.00$ & - & - \\
\hline Propetamphos (0.5) & 40 & $10.00 \pm 8.00$ & - & - \\
\hline Propetamphos (5) & 40 & $10.00 \pm 8.00$ & - & - \\
\hline Propetamphos $(50)$ & 40 & $20.00 \pm 11.00$ & - & - \\
\hline $\begin{array}{l}\text { Propetamphos }(0.5) \pm \\
\quad \text { M. anisopliae }\end{array}$ & 40 & $65.00 \pm 17.00$ & Additive & 1.82 \\
\hline $\begin{array}{l}\text { Propetamphos }(5) \pm \\
\quad \text { M. anisopliae }\end{array}$ & 40 & $65.00 \pm 13.00$ & Additive & 1.82 \\
\hline $\begin{array}{l}\text { Propetamphos }(50) \pm \\
\quad \text { M. anisopliae }\end{array}$ & 40 & $70.00 \pm 12.00$ & Additive & 1.67 \\
\hline \multicolumn{5}{|c|}{ Bioassay 3} \\
\hline $\begin{array}{l}\text { Distilled water }+ \\
\text { Triton X-100 }\end{array}$ & 40 & $7.50 \pm 5.00$ & - & - \\
\hline M. anisopliae & 40 & $57.50 \pm 5.00$ & - & - \\
\hline Propetamphos (100) & 40 & $15.00 \pm 6.00$ & - & - \\
\hline Propetamphos (200) & 40 & $15.00 \pm 6.00$ & - & - \\
\hline Propetamphos (300) & 40 & $27.50 \pm 10.00$ & - & - \\
\hline $\begin{array}{l}\text { Propetamphos }(100) \pm \\
\quad \text { M. anisopliae }\end{array}$ & 40 & $50.00 \pm 11.00$ & Additive & 3.01 \\
\hline $\begin{array}{l}\text { Propetamphos }(200) \pm \\
\quad \text { M. anisopliae }\end{array}$ & 40 & $77.50 \pm 9.00$ & Additive & 2.91 \\
\hline $\begin{array}{l}\text { Propetamphos }(300) \pm \\
\quad \text { M. anisopliae }\end{array}$ & 40 & $92.50 \pm 5.00$ & Synergistic & 7.86 \\
\hline
\end{tabular}

Chi-square values calculated using the formula: (observed \% mortality - expected $\%$ mortality $)^{2} /$ expected $\%$ mortality $\left(\chi^{2}=3.84, \mathrm{df}=\right.$ $1, \alpha=0.05)$.

${ }^{a}$ Each treatment (containing 10 males) were replicated 4 times.

${ }^{b}$ Dashes represent no effect.

${ }^{c}$ Dashes represent no value.

alone $(P=0.0001)$. Mortality ranged from 52.5 to $55 \%$ for cyfluthrin $+M$. anisopliae combinations (Table 4) and the pattern observed with and without spores were similar to chlorpyrifos and propetamphos. There was no significant difference in mortality caused by $M$. anisopliae alone and $8 \mathrm{M}$. anisopliae plus insecticide combinations. The only exception was $M$. anisopliae plus 50 ppm of propetamphos, where the mortality caused by this treatment was significantly higher than the mortality caused by $M$. anisopliae alone $(t=-2.59$, $\mathrm{df}=69, P=0.011$ )

Although higher mortality was observed with $M$. anisopliae plus insecticide combination there was no significant interaction among insecticides, concentrations, and $M$. anisopliae $(F=0.37$; $\mathrm{df}=6,69 ; P=$ $0.8951)$. The slopes for chlorpyrifos, propetamphos, and cyfluthrin with and without $M$. anisopliae were parallel and there were no significant differences between the slopes $(F=1.09 ; \mathrm{df}=2,72 ; P=0.3428)$. We also did not find any interaction between insecticides and $M$. anisopliae $(F=1.06 ; \mathrm{df}=2,69 ; P=0.3521)$, insecticide concentrations and $M$. anisopliae $(F=0.34$; $\mathrm{df}=3,69 ; P=0.7995)$, and insecticides and its concentrations $(F=0.57, \mathrm{df}=6,69 ; P=0.7533)$. Lack of a three-way interaction clearly indicates that there is no synergistic or antagonistic effect among these combinations. Because there is no significant difference
Table 4. Toxicity of cyfluthrin (ppm) and cyfluthrin (ppm) + M. anisopliae $\left(4.18 \times 10^{8}\right.$ spores per milliliter $)$ in German cockroaches after $21 \mathrm{~d}$

\begin{tabular}{|c|c|c|c|c|}
\hline Treatment $(\mathrm{ppm})^{a}$ & $n$ & $\begin{array}{c}\% \text { mortality } \\
\pm \text { SEM }\end{array}$ & Effect $^{b}$ & $\chi^{2}$ \\
\hline \multicolumn{5}{|c|}{ Bioassay 2} \\
\hline Distilled water + Triton X-100 & 40 & $7.50 \pm 5.00$ & - & - \\
\hline M. anisopliae & 40 & $50.00 \pm 14.14$ & - & - \\
\hline Cyfluthrin (0.05) & 40 & $10.00 \pm 8.00$ & - & - \\
\hline Cyfluthrin (0.5) & 40 & $7.50 \pm 5.00$ & - & - \\
\hline Cyfluthrin (5) & 40 & $12.50 \pm 10.00$ & - & - \\
\hline Cyfluthrin $(0.05)+M$. anisopliae & 40 & $55.00 \pm 6.00$ & Additive & 0.00 \\
\hline Cyfluthrin $(0.5)+M$. anisopliae & 40 & $52.50 \pm 17.00$ & Additive & 0.03 \\
\hline Cyfluthrin $(5)+$ M. anisopliae & 40 & $55.00 \pm 13.00$ & Additive & 0.03 \\
\hline \multicolumn{5}{|c|}{ Bioassay 3} \\
\hline Distilled water + Triton X-100 & 40 & .00 & - & - \\
\hline M. anisopliae & 40 & $57.50 \pm 5.00$ & - & - \\
\hline Cyfluthrin (20) & 40 & $20.00 \pm 14.00$ & - & - \\
\hline Cyfluthrin (30) & 40 & $35.00 \pm 10.00$ & - & - \\
\hline Cyfluthrin (40) & 40 & $42.50 \pm 10.00$ & - & - \\
\hline Cyfluthrin $(20)+M$. anisopliae & 40 & $72.50 \pm 10.00$ & Additive & \\
\hline Cyfluthrin $(30)+M$. anisopliae & 40 & $85.00 \pm 6.00$ & Additive & 3.0 \\
\hline Cyfluthrin $(40)+M$. anisopliae & 40 & $85.00 \pm 6.00$ & Additive & 1.1 \\
\hline
\end{tabular}

Chi-square values calculated using the formula: (observed \% mortality - expected $\%$ mortality $)^{2} /$ expected $\%$ mortality $\left(\chi^{2}=3.84, \mathrm{df}=\right.$ $1, \alpha=0.05)$.

${ }^{a}$ Each treatment (containing 10 males) was replicated 4 times.

${ }^{b}$ Dashes represent no effect.

${ }^{c}$ Dashes represent no value.

between insecticides $\times$ M. anisopliae $\times$ concentration, the increased mortality is the result of an additive effect. Thus, mortality observed in the treatment combination is caused by the independent action of both $M$. anisopliae and insecticides. The hypothesis was confirmed by the chi-square test, which indicated an additive effect caused by $M$. anisopliae and insecticides combination study in bioassay 2 .

Enhancing the Combined Effect of M. anisopliae with Higher Sublethal Doses of Insecticides (Bioassay 3 ). Percentage of germination $\pm \mathrm{SE}$ of $M$. anisopliae for the 4 replications used in bioassay 3 was $96 \pm 0.5,95 \pm$ $1.41,95 \pm 1.41$, and $96 \pm 1.26$, respectively. Mortality patterns observed with and without $M$. anisopliae spores and insecticides were similar to those observed in bioassay 2. The mortality for chlorpyrifos $+M$. anisopliae combinations ranged from 57.5 to $90 \%$ ( $\mathrm{Ta}$ ble 2 ), and the mean mortality of the combination was significantly different from chlorpyrifos without the spores $(t=-15.65, \mathrm{df}=69, P=0.0001)$. Propetamphos and cyfluthrin also exhibited a similar effect (Tables 3 and 4) when used in combination with $M$. anisopliae. Mortality ranged from 50 to $92.5 \%$ for the propetamphos + M. anisopliae combination, and 72.5$85 \%$ for cyfluthrin + M. anisopliae combinations, respectively. Mortality caused by M. anisopliae alone was not significantly from the mortality caused by $M$. anisopliae plus 100 ppm of chlorpyrifos $(t=0.00, \mathrm{df}=69$, $P=1.000)$ and propetamphos $(t=1.30, \mathrm{df}=69, P=$ $0.1965)$. But there was a significant difference in mortality caused by $M$. anisopliae alone and $M$. anisopliae plus insecticide in 7 other treatments.

In bioassay 3 , there was a three-way significant interaction among insecticides, concentrations, and $M$. 
anisopliae $(F=3.93, \mathrm{df}=6,69 ; P=0.0019)$. Significant difference in slopes also occurred $(F=4.36 ; \mathrm{df}=2,66$; $P=0.0167)$, indicating nonparallelism. The slopes were different for chlorpyrifos with $(F=16.209$, $\mathrm{df}=$ $2, P=0.003)$ and without spore $(F=25.226, \mathrm{df}=2$, $P=0.0001)$, propetamphos with $(F=20.461, \mathrm{df}=2$, $P=0.0001)$ and without spores $(F=7.687, \mathrm{df}=2, P=$ $0.06)$, and cyfluthrin with $(F=23.149$, df $=2, P=$ $0.0001)$ and without spores $(F=14.861, \mathrm{df}=2, P=$ $0.004)$. Mortality observed at $300 \mathrm{ppm}$ of chlorpyrifos was significantly different from $100(t=-6.96, \mathrm{df}=$ $69, P=0.0001)$ and $200 \mathrm{ppm}(t=-7.39, \mathrm{df}=69, P=$ 0.0001 ) of chlorpyrifos, but there was no difference $(t=0.43, \mathrm{df}=69, P=0.6651)$ in the mortality between 100 and $200 \mathrm{ppm}$ of chlorpyrifos (Table 3). Differences in the slope of the chlorpyrifos $+M$. anisopliae combinations were influenced by concentrations as well as the interaction between concentration and $M$. anisopliae. When M. anisopliae was used with $100 \mathrm{ppm}$ of chlorpyrifos, the mortality observed was similar to the control (M. anisopliae). In addition, high mortality observed at 300 ppm of chlorpyrifos by itself had a significant effect on mortality thereby reducing the interaction effect between chlorpyrifos and M. anisopliae. When propetamphos was used alone, the mortality was not significantly different at 100 and $200 \mathrm{ppm}$ $(t=0.00, \mathrm{df}=69, P=1.000)$. But in the propetamphos + M. anisopliae combination, the mortality increased as the concentration of insecticides increased and this interaction was significant $(F=4.59 ; \mathrm{df}=3$, $69 ; P=0.0054$ ), suggesting a synergistic effect for this combination (Table 4). The mortality was not significantly different (Table 4 ) between 30 and $40 \mathrm{ppm}$ of cyfluthrin with $(t=0.00, \mathrm{df}=69, P=1.000)$ and without M. anisopliae $(t=-1.30, \mathrm{df}=69, P=0.1965)$. The three-way interaction (insecticides $\times$ concentration $\times$ spores) observed in bioassay 3 was influenced by both the interaction between concentration of propetamphos and M. anisopliae as well as the interaction between insecticide and concentration $(F=3.85 ; \mathrm{df}=$ $6,69 ; P=0.0023)$. A chi-square test confirmed that the effects were additive for chlorpyrifos and cyfluthrin, and synergistic for propetamphos.

Calculated $\mathbf{L T}_{50}$ Values for M. anisopliae and Its Combinations with Selected Sublethal Doses of Insecticides. The treatments were not considered significant when there was an overlap in the 95\% CL of lethal time values. There was a significant difference in $\mathrm{LT}_{50}$ between insecticides, M. anisopliae, and insecticide + M. anisopliae (Table 5). The M. anisopliae or insecticide $+M$. anisopliae combinations were more toxic and caused faster mortality than insecticides with the exception of $300 \mathrm{ppm}$ of chlorpyrifos. The $\mathrm{LT}_{50}$ between M. anisopliae and insecticides $+M$. anisopliae (200 and $300 \mathrm{ppm}$ of chlorpyrifos, $300 \mathrm{ppm}$ of propetamphos, and 20,30, and 40 ppm of cyfluthrin) was significantly different and the above mentioned combinations caused faster mortality than M. anisopliae alone. The M. anisopliae alone was more effective than $100 \mathrm{ppm}$ of propetamphos + M. anisopliae and there was no difference between M. anisopliae and 100 ppm of chlorpyrifos + M. anisopliae and $200 \mathrm{ppm}$ of
Table 5. Calculated $\mathrm{LT}_{50}$ values for $M$. anisopliae $\left(4.18 \times 10^{8}\right.$ spores per milliliter) and its combination with selected doses of insecticides

\begin{tabular}{|c|c|c|c|c|c|}
\hline Treatment $^{a}$ & $n$ & $\begin{array}{l}\text { Slope } \pm \\
\text { SE }\end{array}$ & $\mathrm{LT}_{50}^{b}$ & $95 \% \mathrm{CL}^{c}$ & $\chi^{2}$ \\
\hline M. anisopliae & 40 & $3.05 \pm 0.24$ & 15.40 & $14.10-16.70$ & 3.70 \\
\hline Chlorpyrifos 100 & 40 & $1.09 \pm 0.16$ & 73.86 & $54.40-122.13$ & 10.42 \\
\hline Chlorpyrifos 200 & 40 & $4.01 \pm 1.27$ & 52.80 & $48.80-61.65$ & 0.25 \\
\hline Chlorpyrifos 300 & 40 & $0.49 \pm 0.12$ & 4.94 & $1.15-8.94$ & 4.19 \\
\hline $\begin{array}{l}\text { Chlorpyrifos } 100+ \\
\text { M. anisopliae }\end{array}$ & 40 & $2.22 \pm 0.23$ & 17.80 & $15.94-20.01$ & 3.43 \\
\hline $\begin{array}{c}\text { Chlorpyrifos } 200+ \\
\text { M. anisopliae }\end{array}$ & 40 & $1.63 \pm 0.19$ & 6.90 & $5.50-8.24$ & 5 \\
\hline $\begin{array}{c}\text { Chlorpyrifos } 300+ \\
\text { M. anisopliae }\end{array}$ & 40 & $1.28 \pm 0.23$ & 2.29 & $1.10-3.39$ & 3.53 \\
\hline Propetamphos 100 & 40 & $1.49 \pm 0.25$ & 87.74 & $67.81-136.84$ & 1.32 \\
\hline Propetamphos 200 & 40 & $4.11 \pm 0.50$ & 37.93 & $35.57-40.75$ & 1.29 \\
\hline Propetamphos 300 & 40 & $1.32 \pm 0.25$ & 44.39 & $36.63-61.72$ & 2.17 \\
\hline $\begin{array}{l}\text { Propetamphos } 100+ \\
\text { M. anisopliae }\end{array}$ & 40 & $2.11 \pm 0.18$ & 19.26 & $17.15-21.47$ & 3.15 \\
\hline $\begin{array}{l}\text { Propetamphos } 200+ \\
\quad \text { M. anisopliae }\end{array}$ & 40 & $3.46 \pm 0.33$ & 12.86 & $11.49-14.06$ & 2.02 \\
\hline $\begin{array}{l}\text { Propetamphos } 300+ \\
\text { M. anisopliae }\end{array}$ & 40 & $2.11 \pm 0.30$ & 6.44 & $4.97-7.66$ & 5.33 \\
\hline Cyfluthrin 20 & 40 & $1.40 \pm 0.28$ & 64.90 & $50.60-109.00$ & 5.05 \\
\hline Cyfluthrin 30 & 40 & $1.14 \pm 0.17$ & 48.87 & $39.12-69.93$ & 11.40 \\
\hline Cyfluthrin 40 & 40 & $0.61 \pm 0.13$ & 48.78 & $35.22-103.27$ & 1.40 \\
\hline $\begin{array}{l}\text { Cyfluthrin } 20+ \\
\text { M. anisopliae }\end{array}$ & 40 & $1.89 \pm 0.13$ & 12.44 & $10.84-13.99$ & 12.31 \\
\hline $\begin{array}{l}\text { Cyfluthrin } 30+ \\
\text { M. anisopliae }\end{array}$ & 40 & $1.81 \pm 0.28$ & 7.07 & $5.33-8.49$ & 2. \\
\hline $\begin{array}{l}\text { Cyfluthrin } 40+ \\
\text { M. anisopliae }\end{array}$ & 40 & $.28 \pm 0.26$ & 7.46 & $6.12-8.64$ & 5.34 \\
\hline
\end{tabular}

${ }^{a}$ Each treatment (containing 10 males) was replicated 4 times.

${ }^{b}$ Number of days until $50 \%$ mortality occurred after different treatments.

${ }^{c}$ Treatments will have significant effect on $\mathrm{LT}_{50}$ if there was no overlap of $95 \%$ CL.

propetamphos + M. anisopliae. The 300 ppm of chlorpyrifos + M. anisopliae was more toxic than the other insecticides + M. anisopliae. There was no difference in the $\mathrm{LT}_{50}$ among $200 \mathrm{ppm}$ of chlorpyrifos $+M$. anisopliae, $300 \mathrm{ppm}$ of propetamphos + M. anisopliae, $30 \mathrm{ppm}$ of cyfluthrin + M. anisopliae, and $40 \mathrm{ppm}$ of cyfluthrin + M. anisopliae. The above mentioned combinations yielded higher mortality than $100 \mathrm{ppm}$ of chlorpyrifos + M. anisopliae, $100 \mathrm{ppm}$ of propetamphos + M. anisopliae, $200 \mathrm{ppm}$ of propetamphos $+M$. anisopliae and $20 \mathrm{ppm}$ of cyfluthrin + M. anisopliae. The $\mathrm{LT}_{50}$ of $200 \mathrm{ppm}$ of propetamphos + M. anisopliae and $20 \mathrm{ppm}$ of cyfluthrin + M. anisopliae was higher than 100 ppm of chlorpyrifos + M. anisopliae and 100 ppm of propetamphos + M. anisopliae.

Effect on Body Weight from M. anisopliae and Insecticide Plus M. anisopliae During the Infection Process. The body weight of German cockroaches exposed to chlorpyrifos and chlorpyrifos $+M$. anisopliae from 0 to $20 \mathrm{~d}$ ranged between 100 and $107 \%$ (Fig. 1). The body weight of German cockroaches treated with propetamphos and propetamphos $+M$. anisopliae during the same observation period ranged from 100 to $102 \%$ (Fig. 2), whereas body weight for cyfluthrin and cyfluthrin + M. anisopliae ranged from 100 to $105 \%$ (Fig. 3). There was no significant difference in the percentage of body weight of German cockroaches 


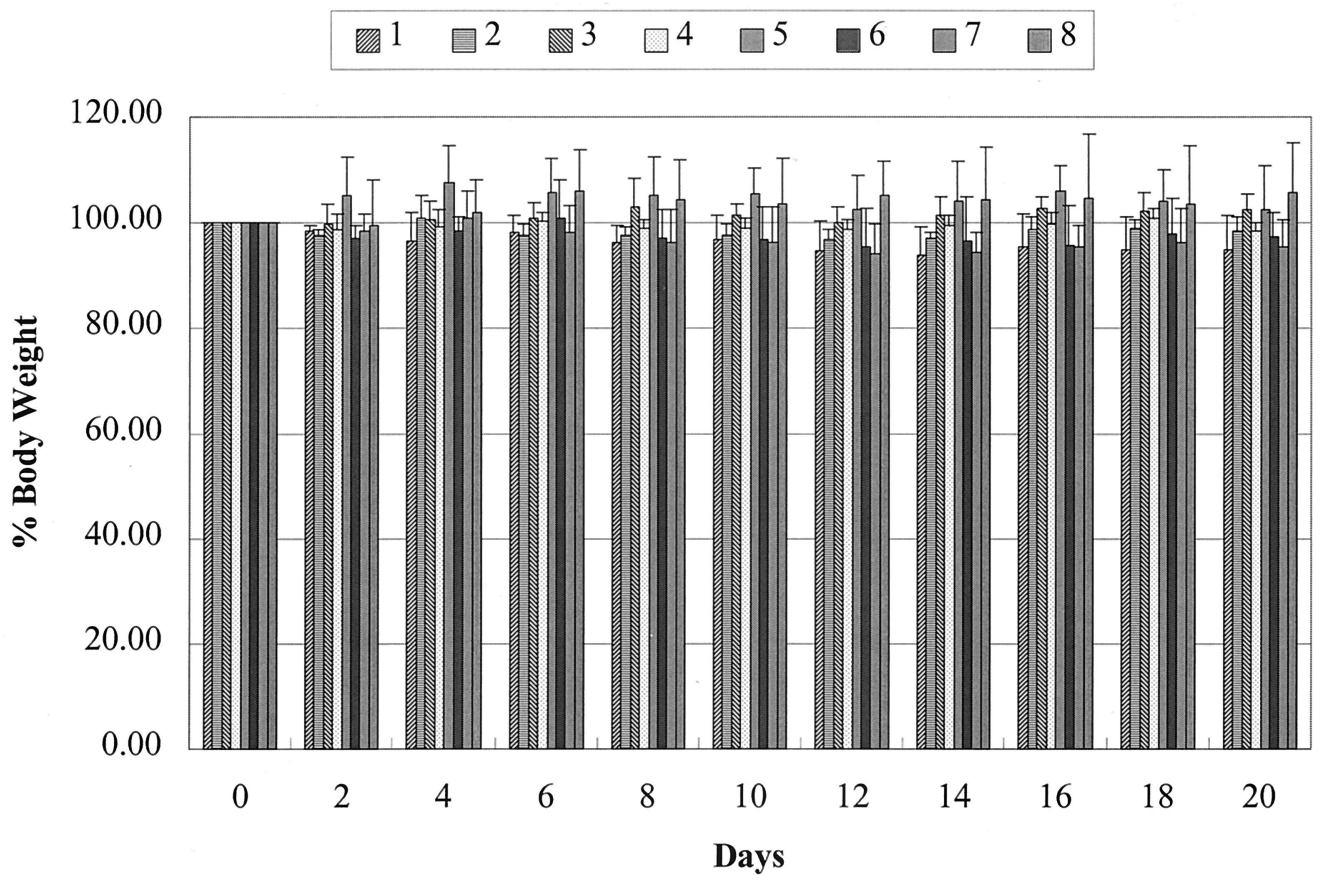

Fig. 1. Effect on body weight of German cockroaches from chlorpyrifos and chlorpyrifos + M. anisopliae $\left(4.18 \times 10^{8}\right.$ spores per milliliter) during the infection process. Treatment $1=0 \mathrm{ppm}+M$. anisopliae, treatment $2=0 \mathrm{ppm}$, treatment $3=100 \mathrm{ppm}$, treatment $4=200 \mathrm{ppm}$, treatment $5=300 \mathrm{ppm}$, treatment $6=100 \mathrm{ppm}+$ M. anisopliae, treatment $7=200$ ppm + M. anisopliae, and treatment $8=300 \mathrm{ppm}+$ M. anisopliae.

during the observation period because of interaction between insecticide $\times$ concentrations $\times$ M. anisopliae $(F=0.96 ; \mathrm{df}=60,720 ; P=0.5607)$. Similarly, body weights during the observation period were not affected by the interaction between insecticides and concentrations $(F=0.71 ; \mathrm{df}=60,720 ; P=0.9494)$. Body weight was not affected significantly by individual effect of insecticide $(F=1.08 ; \mathrm{df}=20,720 ; P=$ $0.3643)$, concentration $(F=1.01 ; \mathrm{df}=30,720 ; P=$ $0.4597)$ and $M$. anisopliae $(F=1.17 ; \mathrm{df}=10,720 ; P=$ $0.3077)$. The result clearly indicates that $M$. anisopliae or insecticide $+M$. anisopliae did not affect the body weight of German cockroaches during the infection period.

\section{Discussion}

In our study, the M. anisopliae strain ESC-1 by itself was effective and caused $\approx 50-57 \%$ mortality at the lethal concentration of $4.18 \times 10^{8}$ spores per milliliter (Pachamuthu et al. 1999) in $21 \mathrm{~d}$. Earlier studies by Gunner et al. (1991), Kaakeh et al. (1996, 1997), and Pachamuthu et al. (1999) also demonstrated the effectiveness of $M$. anisopliae in controlling German cockroaches. Despite being an effective biopesticide agent, different strains of $M$. anisopliae require 21-42 $\mathrm{d}$ to achieve $90 \%$ mortality. For entomopathogens to be effective, the conidia must attach and penetrate the insect cuticle and this process is influenced by a nonspecific, passive hydrophobic interaction between conidia and insect cuticle (Boucias et al. 1988). The efficiency of conidial binding to the insect cuticle is also influenced by the structure and chemical properties of cuticle (Butt et al. 1995, Sosa-Gomez et al. 1997). After binding to the insect cuticle it takes 48-96 $\mathrm{h}$ to develop a germ tube and appressorium (Vey et al. 1982, Butt et al. 1995, Boucias et al. 1996). Subsequently, the germ tube will continue to grow by using the insect cuticle as a substrate, which is facilitated by both enzymatic action (lipases, proteases, and chitinases), and mechanical force (St. Leger et al. 1986, Tanada and Kaya 1993). The hyphae then penetrate the cuticle, enter the hemocoel, and form hyphal bodies or blastospores (Roberts and Yendol 1971, Tanada and Kaya 1993). When the penetrating hyphae of entomopathogens reach the hemocoel, the invading hyphae are challenged by the insect cellular response. Insects respond either by nodule formation (Gunnarsson and Lackie 1985, Hajek and St. Leger 1994) or by encapsulation and melanization (Beauvais et al. 1989, Hajek and St. Leger 1994). Eventually, the fungus will overcome the encapsulation and produce blastospores or hyphal bodies. In addition to factors listed by Kaakeh et al. (1996), the infection process of the fungus and cellular response of insect also contribute to longer times required by M. anisopliae to cause a significant impact on mortality.

Even if significant improvement can be made with the design and formulation of M. anisopliae delivery system, the entomopathogens still require an infection 


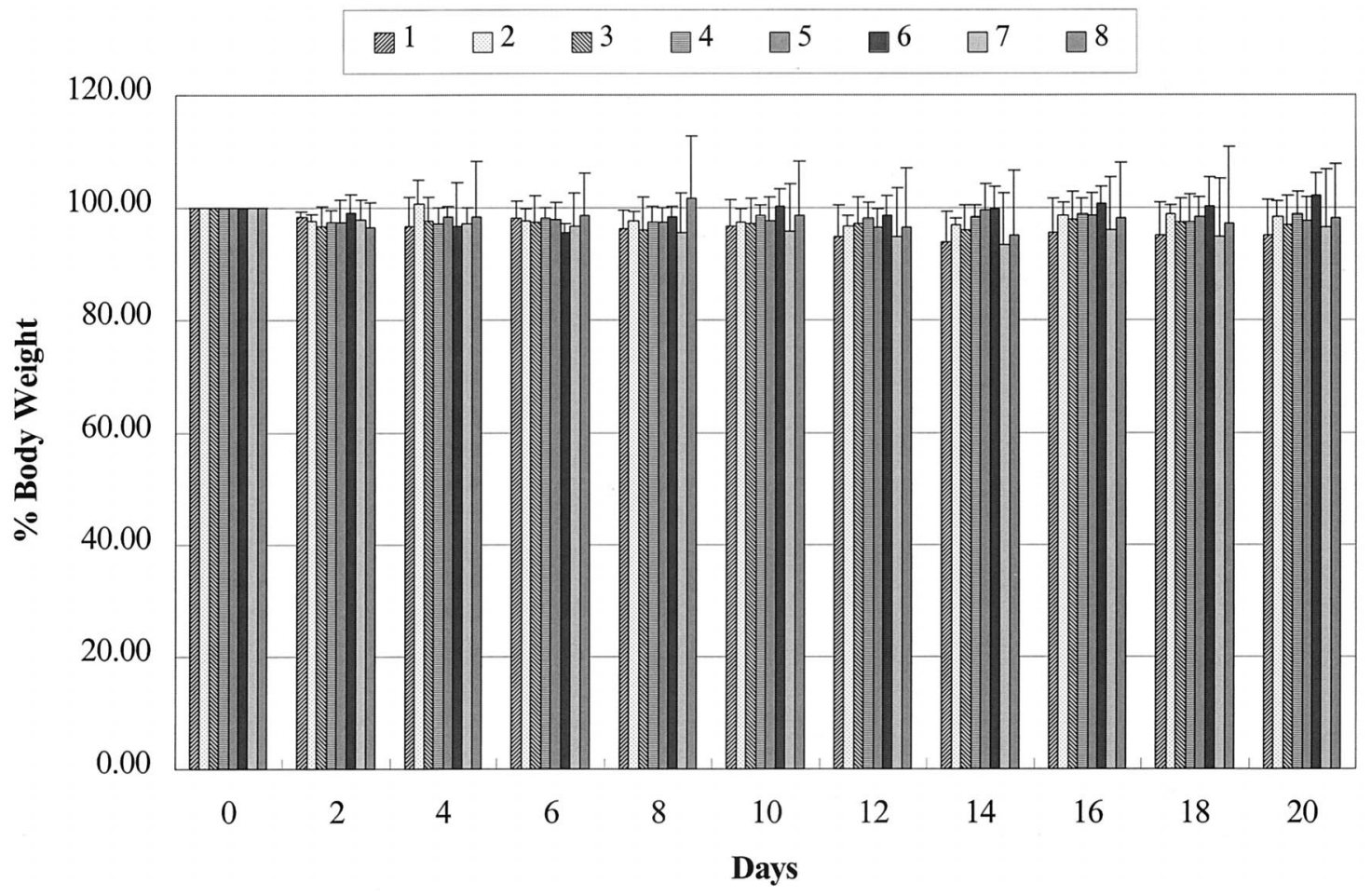

Fig. 2. Effect on body weight of German cockroaches from propetamphos and propetamphos + M. anisopliae $(4.18 \times$ $10^{8}$ spores per milliliter) during the infection process. Treatment $1=0 \mathrm{ppm}+$ M. anisopliae, treatment $2=0 \mathrm{ppm}$, treatment $3=100 \mathrm{ppm}$, treatment $4=200 \mathrm{ppm}$, treatment $5=300 \mathrm{ppm}$, treatment $6=100 \mathrm{ppm}+$ M. anisopliae, treatment $7=200$ ppm + M. anisopliae, and treatment $8=300 \mathrm{ppm}+$ M. anisopliae.

period to be an effective biopesticide agent. In our study, the hypothesis that using $M$. anisopliae in combination with sublethal doses of insecticides would enhance the total toxic effect of $M$. anisopliae as a biopesticide for controlling German cockroaches was clearly demonstrated in bioassay 2 and 3. Bioassays 2 and 3 illustrated that morality caused by insecticide + M. anisopliae was significantly greater than the morality caused by insecticide alone. This action could be justified because M. anisopliae was used as a primary agent of control, whereas the insecticide was used to enhance the action of M. anisopliae and was not relied upon to cause any significant mortality. Sublethal doses of insecticide might weaken the defense and immune response in insects to $M$. anisopliae infection (Hiromori and Nishigaki 1998). Reduced mortality by insecticides compared with M. anisopliae + insecticides was also reported by Hiromori and Nishigaki (1998), whereas Sanyang and Van Emden (1996) observed similar results with M. flavoviride Gams \& Rozsypal + cypermethrin. Bioassays 2 and 3 further demonstrated that mortality caused by certain combinations of insecticide + M. anisopliae was significantly higher than M. anisopliae alone. Eight of 18 insecticide $+M$. anisopliae combinations had significantly higher mortality than M. anisopliae alone. The average mortality of 7 of 9 insecticide $+M$. anisopliae combinations increased from bioassay 2 to bioassay 3 by increasing sublethal concentration of insecticides and mortality was significantly different from M. anisopliae alone in these combinations.

A similar pattern was also observed in the $\mathrm{LT}_{50}$ study. The $\mathbf{L T}_{50}$ values were similar or lower in most of the insecticide plus M. anisopliae combinations in comparison with $M$. anisopliae alone, the only exception was $100 \mathrm{ppm}$ of propetamphos. The $\mathrm{LT}_{50}$ of 100 ppm of chlorpyrifos was numerically higher than $M$. anisopliae alone but the lethal time and mortality between these treatments were not significantly different. Between 200 and 300 ppm of chlorpyrifos in combination with $M$. anisopliae is required to significantly influence lethal time and mortality in German cockroaches. Lack of significant difference in the $\mathrm{LT}_{50}$ between $300 \mathrm{ppm}$ of chlorpyrifos alone and in combination with M. anisopliae indicates that this concentration by itself causes high initial mortality but survivors are then greatly affected by $M$. anisopliae. Significant differences in $\mathrm{LT}_{50}$ between M. anisopliae and $100 \mathrm{ppm}$ of propetamphos plus M. anisopliae does not indicate an antagonistic effect because there was no significant difference in the mortality percentage between these 2 treatments. Similarly, at $200 \mathrm{ppm}$ of propetamphos plus $M$. anisopliae there was a significant difference in the mortality percentage in comparison to M. anisopliae but there was no significant difference in the lethal time. In both treatments, the 


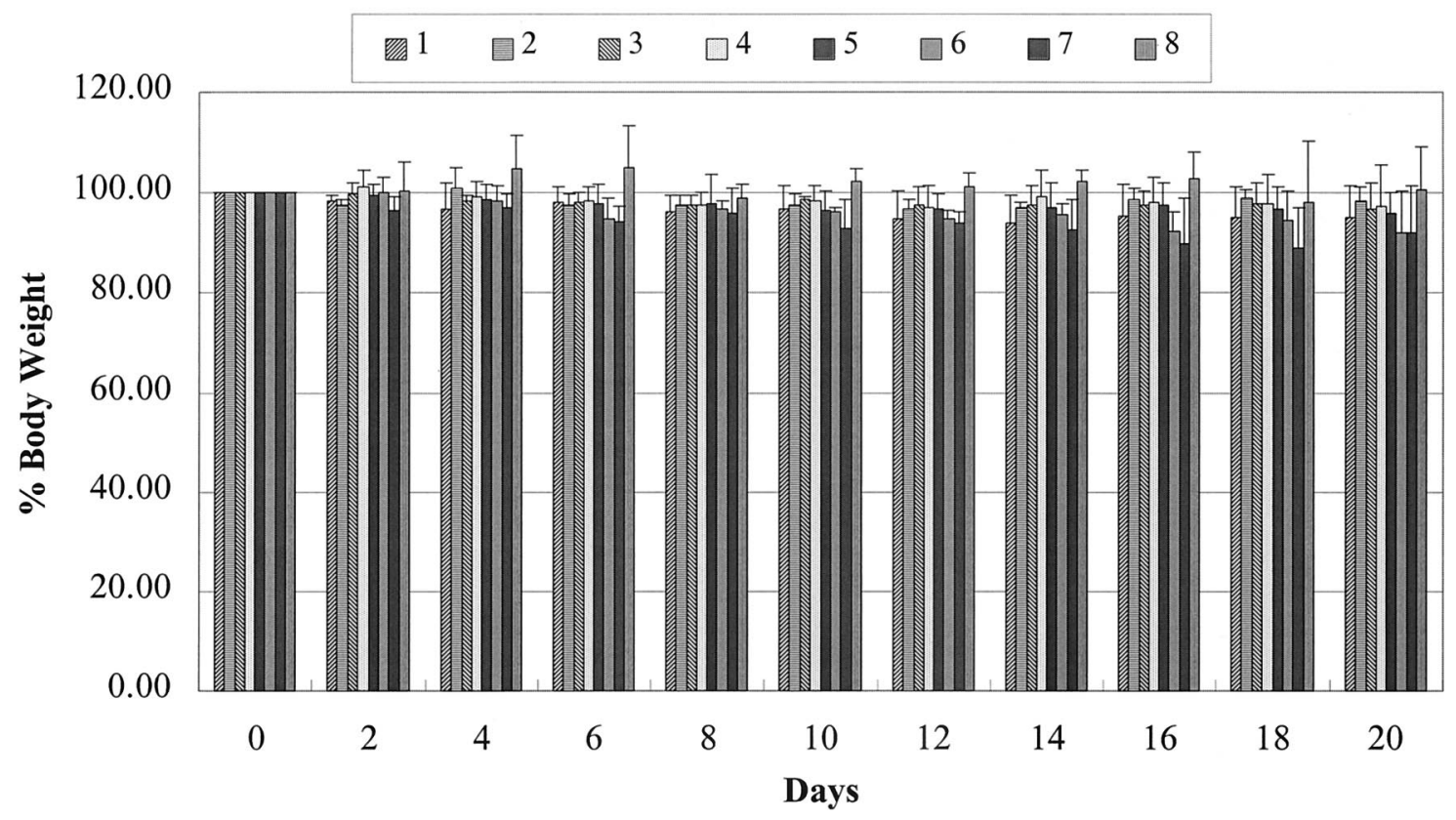

Fig. 3. Effect on body weight of German cockroaches from cyfluthrin and cyfluthrin + M. anisopliae $\left(4.18 \times 10^{8}\right.$ spores per milliliter) during the infection process. Treatment $1=0 \mathrm{ppm}+$ M. anisopliae, treatment $2=0 \mathrm{ppm}$, treatment $3=20$ ppm,treatment $4=30 \mathrm{ppm}$, treatment $5=40 \mathrm{ppm}$, treatment $6=20 \mathrm{ppm}+$ M. anisopliae, treatment $7=30 \mathrm{ppm}+$ M. anisopliae, and treatment $8=40 \mathrm{ppm}+\mathrm{M}$. anisopliae.

overall mortality effects were additive indicating that propetamphos does not inhibit the action of $M$. anisopliae but it delays the lethal time required to cause $50 \%$ mortality in comparison with M. anisopliae. Even though synergistic effects were not observed with cyfluthrin, doses ranging from 20 to $40 \mathrm{ppm}$ of cyfluthrin in combination with M. anisopliae were effective in reducing lethal time and increasing mortality in German cockroaches in comparison with $M$. anisopliae. Thus, increased mortality and lowered $\mathrm{LT}_{50}$ values were a general pattern observed in most of insecticide + M. anisopliae combinations against German cockroaches in our study. Kaakeh et al. (1997) also reported that $\mathrm{LT}_{50}$ decreased as the concentration of M. anisopliae increased in combination with selected doses of imidacloprid.

When 2 products are used together they might act independently or one agent may stress the insect which enables the second agent to be more effective (Sanyang and Van Emden 1996, Hiromori and Nishigaki 1998). Increased mortality observed in our study was caused by insecticide concentration and not influenced by the type of insecticide. Between the 2 organophosphates tested in our study, propetamphos produced higher mortality with $M$. anisopliae than did chlorpyrifos. Moreover, chlorpyrifos (organophosphate) and cyfluthrin (pyrethroid) exhibited a similar combination effect with $M$. anisopliae compared with propetamphos. Although concentration did not influence the action of the spores (no interaction between concentration $\times$ M. anisopliae $)$ with chlorpyrifos $(0.5$ $300 \mathrm{ppm})$ and cyfluthrin (0.05-40 ppm), increased mortality was observed as a result of the independent action of both concentration and spores. Lower concentrations of propetamphos (0.5-200 ppm) also acted in a similar manner to chlorpyrifos and cyfluthrin, but at high concentration of propetamphos (300 ppm), concentration enhanced the effect of the spores on cockroach mortality. The additive effects of entomopathogens and insecticides were reported by $\mathrm{Hi}$ romori and Nishigaki (1998), whereas synergistic effects were also reported by Kaakeh et al. (1997) for controlling German cockroaches with imidacloprid + M. anisopliae, and Quintela and McCoy (1997) for controlling the root weevil Diaprepes abbreviatus (L.) with imidacloprid + M. anisopliae. Results observed in our study and other studies (Anderson and Roberts 1983, Salama et al. 1984, Charnley 1989, Sanyang and Van Emden 1996, Hiromori and Nishigaki 1998) clearly indicate that entomopathogens are compatible with some insecticides and microbial agents. Studies of insecticides plus entomopathogens further demonstrate that integrating insecticides and entomopathogens is an option with significant impact on pest mortality, and such an integrated approach will increase pest mortality as well as reduce the lethal time to cause the equivalent effect in comparison to entomopathogens alone. Moreover, high mortality achieved with sublethal doses of insecticide plus entomopathogens may also prolong the use of a particular insecticide by reducing the total amount of insecticide used, minimizing environmental contamination, and increasing human safety. 


\section{Acknowledgments}

We thank Gary Yuen and Mischell Craig (Department of Plant pathology) for the laboratory space and assistance in culturing the fungal colony. We are grateful to Linda Young and Anabayan Kessavalou (Department of Biometry) for their technical advice in data analysis. We also thank Michael Scharf and Marion Ellis for their critical review of the manuscript. This project was funded in part through an interdisciplinary research program by the Agricultural Research Division, University of Nebraska, Lincoln. This is published as paper no. 12351, Journal Series, Nebraska Agricultural Division and contribution no. 1003, Department of Entomology, University of Nebraska-Lincoln.

\section{References Cited}

Anderson, T. E., and D. W. Roberts. 1983. Compatibility of Beauveria bassiana isolates with insecticide formulations used in Colorado potato beetles (Coleoptera: Chrysomelidae) Control. J. Econ. Entomol. 76: 1437-1441.

Anderson, T. E., A. E. Hajek, D. W. Roberts, H. K. Preisler, and J. L. Robertson. 1989. Colorado potato beetle (Coleoptera: Chrysomelidae): effects of combinations of Beauveria bassiana with insecticides. J. Econ. Entomol. 82: 83-89.

Beauvais, A., J. P. Latge, A. Vey, and M. C. Prevost. 1989. The role of surface components of the entomopathogenic fungus Entomophaga aulicae in the cellular immune response of Galleria mellonella (Lepidoptera). J. Gen. Microbiol. 135: 489-498.

Benson, E. P., and P. A. Zungoli. 1997. Cockroaches, pp. 123-204. In S. A. Hedge and D. Moreland [eds.], Handbook of pest control. The behavior, life history and control of household pests, 8th ed. Pest Control Technology, Cleveland, $\mathrm{OH}$.

Boucias, D. G., J. C. Pendland, and J. P. Latge. 1988. Nonspecific factors involved in attachment of entomopathogenic Deutromycetes to host insect cuticle. Appl. Environ. Microbiol. 54: 1795-1805.

Boucias, D. G., C. Stokes, G. Storey, and J. C. Pendland. 1996. The effects of imidacloprid on the termite Reticulitermes flavipes and its interaction with the mycopathogen Beauveria bassiana. Pflanzenschutz-Nachr. Bayer 49: 103-144.

Butt, T. M., L. Ibrahim, S. J. Clark, and A. Beckett. 1995. The germination behavior of Metarhizium anisopliae on the surface of aphid and flea beetle cuticles. Mycol. Res. 99: 945-950.

Charnley, A. K. 1989. Mycoinsecticides: present and future prospects, pp. 165-180. In N. R. McFarlane [ed.], Progress and prospects in insect control. Monographs 43. British Crop Protection, Surrey, UK.

Cochran, D. G. 1987. Selection for pyrethroid resistance in the German cockroach (Dictyoptera: Blattellidae). J. Econ. Entomol. 80: 1117-1121.

Cochran, D. G. 1989. Monitoring for insecticide resistance in field-collected strains of the German cockroach (Dictyoptera: Blattellidae). J. Econ. Entomol. 82: 336-341.

Gunner, H. B., F. A. Silva, and C. A. Johnson. 1991. Method and device for biological control of cockroaches. U. S. Patent 5057315.

Gunnarsson, S.G.S., and A. M. Lackie. 1985. Hemocytic aggregation in Schistocerca gregaria and Periplaneta americana as a response to injected substance of microbial origin. J. Invertebr. Pathol. 46: 312-319.

Hajek, A. E. 1989. Food consumption by Lymantria dispar (Lepidoptera: Lymantriidae) larvae infected with Ento- mophaga maimaiga (Zygomycetes: Entomophthorales). Environ. Entomol. 18: 723-727.

Hajek, A. E., and R. J. St. Leger. 1994. Interactions between fungal pathogens and insect hosts. Annu. Rev. Entomol 39: $293-322$

Hemingway, J., G. J. Small, and A. G. Monro. 1993. Possible mechanisms of organophosphorus and carbamate insecticide resistance in German cockroaches (Dictyoptera: Blattellidae) from different geographical areas. J. Econ. Entomol. 86: 1623-1630.

Hiromori, H., and J. Nishigaki. 1998. Joint action of an entomopathogenic fungus (Metarhizium anisopliae) with synthetic insecticides against the Scarab beetle, Anomala cuprea (Coleoptera: Scarabaeidae) larvae. Appl. Entomol. Zool. 33: 77-84.

Kaakeh, W., B. L. Reid, and G. W. Bennett. 1996. Horizontal transmission of the entomopathogenic fungus Metarhizium anisopliae (Imperfect fungi: Hyphomycetes) and hydramethylnon among German cockroaches (Dictyoptera: Blattellidae). J. Entomol. Sci. 31: 378-390.

Kaakeh, W., B. L. Reid, T. J. Bohnert, and G. W. Bennet. 1997. Toxicity of imidacloprid in the German cockroach (Dictyoptera: Blattellidae), and the synergism between imidacloprid and Metarhizium anisopliae (Imperfect fungi: Hyphomycetes). J. Econ. Entomol. 90: 473-482.

Kelley-Tunis, K. K., B. L. Reid, and M. Andis. 1995. Activity of entomopathogenic fungi in free-foraging workers of Camponotus pennsylvanicus (Hymenoptera: Formicidae). J. Econ. Entomol. 88: 937-943.

Lacey, L. A., and A. H. Undeen. 1986. Microbial control of black flies and mosquito. Annu. Rev. Entomol. 31: 265296.

LeOra Software. 1991. POLO-PC: a user's guide to probit or loit analysis. LeOra Software, Berkeley, CA.

Li, D. P., and D. G. Holdom. 1994. Effects of pesticides on growth and sporulation of Metarhizium anisopliae (Deuteromycotina: Hyphomycetes). J. Invertebr. Pathol. 63: 209-211.

McCoy, C. W. 1990. Entomopathogenic fungi as microbial pesticides, pp. 139-159. In R. R. Baker and P. E. Dunn [eds.], New directions in biological control: alternatives for suppressing agricultural pests and diseases. Liss, New York.

Moore, D., M. Reed, G. L. Patourel, Y. J. Abraham, and C. Prior. 1992. Reduction of feeding by desert locust, Schistocerca gregaria, after infection with Metarhizium flavoviride. J. Invertebr. Pathol. 60: 304-307.

Moorhouse, E. R., A. T. Gillespie, E. K. Sellers, and A. K. Charnley. 1992. Influence of fungicides and insecticides on the entomogenous fungus Metarhizium anisopliae, a pathogen of vine weevil, Otiorhynchus sulcatus. Biocontrol Sci. Tech. 2: 49-58.

Morris, O. N., M. Trottier, N. B. McLaughlin, and V. Converse. 1994. Interaction of caffeine and related compounds with Bacillus thuringiensis spp. kurstaki in bertha armyworm (Lepidoptera: Noctuidae). J. Econ. Entomol. 87: $610-617$.

Pachamuthu, P., S. T. Kamble, and G. Y. Yuen. 1999. Virulence of Metarhizium anisopliae (Deuteromycotina: Hyphomycetes) strain ESC-1 to German cockroach (Dictyoptera: Blattellidae) and its compatibility with insecticides. J. Econ. Entomol. 92: 340-346.

Quintela, D. E., and C. W. McCoy. 1997. Pathogenicity enhancement of Metarhizium anisopliae and Beauveria bassiana to first instars of Diaprepes abbreviatus (Coleoptera: Curculionidae) with sublethal doses of imidacloprid. Environ. Entomol. 26: 1173-1182. 
Quintela, D. E., and C. W. McCoy. 1998. Synergistic effect of imidacloprid and two entomopathogenic fungi on the behavior and survival of larvae of Diaprepes abbreviatus (Coleoptera: Curculionidae) in soil. J. Econ. Entomol. 91: $110-112$.

Richter, A. R., and J. R. Fuxa. 1984. Pathogen-pathogen and pathogen-insecticide interactions in velvetbean caterpillar (Lepidoptera: Noctuidae). J. Econ. Entomol. 77: 15591564 .

Roberts, D. W., and W. G. Yendol. 1971. Use of fungi for microbial control of insects, pp. 125-146. In H. D. Burges and N. W. Hussey [eds.], Microbial control of insects and mites, Academic, New York.

Robertson, J. L., and H. K. Preisler. 1992. Pesticide bioassays with arthropods. CRC, Ann Arbor, MI.

Rust, M. K., and D. A. Reierson. 1991. Chlorpyrifos resistance in German cockroaches (Dictyoptera: Blattellidae) from restaurants. J. Econ. Entomol. 84: 736-740.

Rust, M. K., D. A. Reierson, and B. C. Zeichner. 1993. Relationship between insecticide resistance and performance in choice tests of field-collected German cockroaches (Dictyoptera: Blattellidae). J. Econ. Entomol. 86: 1124-1130.

Salama, H. S., M. S. Foda, F. N. Zaki, and S. Moawad. 1984. Potency of combinations of Bacillus thuringiensis and chemical insecticides on Spodoptera littoralis (Lepidoptera: Noctuidae). J. Econ. Entomol. 77: 885-890.

Samuels, K.D.Z., D. E. Pinnock, and P. G. Allsopp. 1989. The potential of Metarhizium anisopliae (Metschnikoff) Sorokin (Deutromycotina: Hypomycetes) as a biological control agent of Inopus rubriceps (Macquart) (Diptera: Stratiomyidae). J. Aust. Entomol. Soc. 28: 69-74.

Sanyang, S., and H. F. Van Emden. 1996. The combined effects of the fungus Metarhizium flavoviride Gams and Rozsypal and the insecticide cypermethrin on Locusta migratoria migratorioides (Reiche and Fairmaire) in the laboratory. Int. J. Pest. Manage. 42: 183-187.
SAS Institute. 1996. SAS systems for windows, version 6.12 SAS Institute, Cary, NC.

Scott, J. G., D. G. Cochran, and B. D. Siegfried. 1990. Insecticide toxicity, synergism and resistance in the German cockroach (Dictyoptera: Blatellidae). J. Econ. Entomol. 83: 1698-1703.

Sosa-Gomez, D. R., D. G. Boucias, and J. L. Nation. 1997. Attachment of Metarhizium anisopliae to the southern green stink bug Nezara viridula cuticle and fungistatic effect of cuticular lipids and aldehydes. J. Invertebr. Pathol. 69: 31-39.

St. Leger, R. J., R. M. Copper, and A. K. Charnley. 1986. Cuticle-degrading enzymes of entomopathogenic fungi: cuticle degradation in vitro by enzymes from entomopathogens. J. Invertebr. Pathol. 47: 167-177.

Tanada, Y., and H. K. Kaya. 1993. Insect pathology. Academic, New York.

Tedders, W. L. 1981. In vitro inhibition of the entomopathogenic fungi Beauveria bassiana and Metarhizium anisopliae by six fungicides used in pecan culture. Environ. Entomol. 10: 346-349.

Vey, A., J. Fargues, and P. Robert. 1982. Histological and ultrastructural studies of factors determining the specificity of pathotypes of the fungus Metarhizium anisopliae for scarabeid larvae. Entomophaga 27: 387-397.

Zhai, J., and W. H. Robinson. 1992. Measuring cypermethrin resistance in the German cockroaches (Orthoptera: Blattellidae). J. Econ. Entomol. 85: 348-351.

Zimmermann, G. 1993. The entomopathogenic fungus Metarhizium anisopliae and its potential as a biological agent. Pestic. Sci. 37: 375-379. 1999.

Received for publication 6 May 1999; accepted 22 September 